\title{
PRODUKTIVITAS Indigofera zollingeriana PADA BERBAGAI INTERVAL PEMOTONGAN
}

\author{
Devi M. A. Sambuaga, M. M. Telleng, S. D. Anis, Constantyn I. J. Sumolang \\ Fakultas Peternakan Universitas Sam Ratulangi, Manado 95115
}

\begin{abstract}
ABSTRAK
Penelitian ini bertujuan untuk mengetahui pengaruh interval pemotongan terhadap produksi daun dan batang serta rasio daun/batang Indigofera zollingeriana. Penelitian ini menggunakan Rancangan Acak Lengkap (RAL) dengan 4 perlakuan dan 5 ulangan. Perlakuan pada penelitian ini adalah: 1) $\mathrm{I}_{1}$ (umur pemotongan 30 hari), 2) $I_{2}$ (umur pemotongan 40 hari), 3) $I_{3}$ (umur pemotongan 50 hari), dan 4) $\mathrm{I}_{4}$ (umur pemotongan 60 hari). Hasil analisis menunjukkan bahwa umur pemotongan berpengaruh yang berbeda sangat nyata $(\mathrm{P}<0,01)$ terhadap produksi segar batang dan daun, produksi bahan kering batang dan daun, serta rasio daun-batang Indigofera zollingeriana. Produksi batang segar dan kering Indigofera zollingeriana pada umur pemotongan 60 hari sangat nyata $(\mathrm{P}<0,01)$ lebih tinggi dari umur pemotongan 30 , 40, hari tetapi, berbeda tidak nyata $(\mathrm{P}>0,05)$ dari interval pemotongan 50 hari. Produksi daun segar dan kering Indigofera zollingeriana pada umur pemotongan 60 hari sangat nyata $(\mathrm{P}<0,01)$ lebih tinggi dari umur pemotongan 30, dan 40 hari tetapi, berbeda tidak nyata $(\mathrm{P}>0,05)$ dari interval pemotongan 50 hari. Rasio daun/batang Indigofera zollingeriana pada umur pemotongan 50 hari sangat nyata $(\mathrm{P}<0,01)$ lebih tinggi dari umur pemotongan 30 dan 40 hari tetapi, berbeda tidak nyata $(\mathrm{P}>0,05)$ dari interval pemotongan 60 hari.
\end{abstract}

*Korespondensi (corresponding author): Email: adetelleng@gmail.com
Disimpulkan bahwa produktivitas indigofera tertinggi yaitu pada umur pemotongan 50 hari.

Kata kunci : Indigofera zollingeriana, interval pemotongan, produktivitas.

\section{ABSTRACT}

THE PRODUCTIVITY OF Indigofera zollingeriana ON INTERVAL CUTTING.This research aims to know the effect of interval cutting on productivity of Indigofera zollingeriana underneath coconut plantation. The study was done based on completely randomized design (CRD) with 4 treatments and 5 replications. The treatments in this study were : 1) $\mathrm{I}_{1}$ (cutting interval 30 days), 2) $\mathrm{I}_{2}$ (cutting interval 40 days), 3) $\mathrm{I}_{3}$ (cutting interval 50 days) and 4) $\mathrm{I}_{4}$ (cutting interval 60 days). The results showed that the effect of cutting interval significantly $(\mathrm{P}<0.01)$ affect fresh and dry weight leaf and stem, and leaf/stem ratio Indigofera zollingeriana. Cutting interval 60 days have significantly $(\mathrm{P}<0,01)$ fresh and dry weight stem of Indigofera zollingeriana than cutting interval 30,40 days but, there was no significant difference $(\mathrm{P}>0,05)$ from the 50 days cutting interval. Cutting interval 60 days have significantly $(\mathrm{P}<0,01)$ fresh and dry weight leaf of Indigofera zollingeriana than cutting interval 30 and 40 days but, there was no significant difference $(\mathrm{P}>0,05)$ from the 50 days cutting interval.Cutting interval 50 days have significantly $(\mathrm{P}<0,01)$ leaf-stem ratio of Indigofera zollingeriana than cutting interval 30 and 40 days but, there was no significant difference $(\mathrm{P}>0,05)$ from the 60 
days cutting interval. It can be concluded that cutting interval 50 days have highly productivity.

Key word : Indigofera zollingeriana, cutting interval, productivity

\section{PENDAHULUAN}

Hijauan pakan sudah sejak dahulu dibudidayakan dengan tujuan untuk memenuhi kebutuhan pakan ternak. Kendala umum yang biasa dialami oleh peternak di pedesaan adalah rendahnya produktivitas ternak. Hal tersebut diakibatkan karena kuantitas dan kualitas pakan yang rendah sehingga produksi ternak juga rendah.

Penyediaan hijauan pakan yang berkualitas mutlak diperlukan dalam rangka meningkatkan produksi dan produktivitas ternak ruminansia (Telleng et al., 2016). Indigofera zollingeriana dapat digunakan sebagai hijauan pakan ternak dan suplemen kualitas tinggi untuk ternak karena kandungan nutrisinya yang tinggi. Tanaman ini memiliki kandungan protein $24,57 \%$, serat kasar $18,18 \%$, kalsium $1,59 \%$, fosfor $0,22 \%$, dan $\mathrm{ADF} 28,85 \%$ (Herdiawan, 2013).

Interval pemotongan sangat mempengaruhi kualitas dan produksi tanaman. Semakin lama suatu tanaman dipotong, kemungkinan produksi akan meningkat, kandungan serat kasar akan meningkat dan sebaliknya nilai gizi semakin menurun karena banyak zat makanan yang hilang untuk di ubah menjadi buah atau biji. Demikian pula sebaliknya apabila pemotongan dilakukan lebih awal atau dilakukan dalam interval pemotongan yang pendek maka kemungkinan yang terjadi kandungan protein tinggi, kandungan air juga tinggi, sedangkan produksinya rendah (Setyaningrum et al., 2017).

Kualitas nutrisi Indigofera zollingeriana dipengaruhi oleh produktivitas hijauan, seperti proporsi daun dan batang. Berdasarkan hal tersebut diperlukan adanya informasi mengenai produktivitas (produksi segar, produksi bahan kering, serta rasio daun dan batang) hijauan Indigofera zollingeriana. Oleh karena itu perlu dilakukan penelitian untuk mengetahui interval pemotongan berpengaruh terhadap produktivitas (produksi berat segar, produksi berat kering, serta rasio daun dan batang) hijauan Indigofera zollingeriana.

\section{MATERI DAN METODE PENELITIAN}

\section{Waktu dan Tempat Penelitian}

Penelitian ini telah dilaksanakan di kebun percobaan milik Balai Pengkaji Teknologi Pertanian (BPTP) yang terletak didesa Talawaan Bantik, Kecamatan Wori, 
Kabupaten Minahasa Utara Provinsi

Sulawesi Utara. Pelaksanaan penelitian ini dimulai pada bulan Desemeber 2019-Mei 2020.

\section{Materi Penelitian}

Materi yang digunakan pada penelitian ini meliputi bahan dan alat. Bahan yang digunakan antara lain: Indigofera zollingeriana berasal dari laboratorium Agrostologi Institut Pertanian Bogor. Alat yang digunakan antara lain: alat tulis, kamera, polybag, alat timbang, gergaji, alat ukur, nampan, alas jemur, kantong plastik besar, kantong kertas, kertas label, plastik, dan gunting.

\section{Metode Penelitian}

Penelitian ini menggunakan Rancangan Acak Lengkap (RAL) menurut petunjuk Stell and Torrie (1995), yang terdiri dari 4 perlakuan interval pemotongan masing-masing perlakuan diulang sebanyak 5 kali.

Perlakunan interval pemotongan yaitu :

\section{$\mathrm{I}_{1}: 30$ hari}

$\mathrm{I}_{2:} 40$ hari

$\mathrm{I}_{3}: 50$ hari

I4: 60 hari

Luasan petak percobaan $3 \mathrm{~m} \times 4 \mathrm{~m}$, di areal pertanaman kelapa yang mempunyai jarak tanam antar pohon kelapa $10 \mathrm{~m}$ x $10 \mathrm{~m}$.

\section{Variabel yang diukur:}

1. Produksi berat segar daun

Produksi berat segar daun dihitung berdasarkan total produksi/panen (g/tanaman).

2. Produksi berat segar batang

Produksi berat segar batang dihitung berdasarkan total produksi/panen (g/tanaman).

3. Produksi berat kering daun

Produksi bahan kering daun dihitung berdasarkan produksi berat segar dikali dengan kandungan bahan kering.

4. Produksi berat kering batang

Produksi bahan kering batang dihitung berdasarkan produksi berat segar dikali dengan kandungan bahan kering.

5. Rasio daun dan batang

Rasio daun dan batang di hitung berdasarkan perbandingan antara jumlah berat daun kering dan batang kering.

\section{Prosedur Penelitian}

Tahapan perlakuan penelitian ini adalah sebagai berikut:

1. Pengolahan tanah

Sebelum pengolahan tanah, tedahulu dilakukan pembersihan lahan, setelah bersih dilakukan pembajakan dengan traktor untuk memecahkan lapisan tanah menjadi bongkahan-bongkahan dan membalikkan lapisan tanah kemudian dibiarkan selama 2 minggu. Selanjutnya tanah digemburkan dengan menggunakan traktor/cangkul sehingga menjadi struktur 
yang remah, sekaligus membersihkan sisasisa perakaran gulma.

2. Pembuatan demplot

Penentuan petak percobaan dalam demplot dilakukan secara acak. Petak percobaan terdiri dari 20 petak masingmasing berukuran $3 \mathrm{~m} \times 4 \mathrm{~m}$ dalam 1 petakan ada 12 tanaman, dengan jarak antar petak $1 \mathrm{~m}$.

3. Penyiapan bibit

Bibit Indigofera zollingeriana diperoleh dari laboratorium Agrostologi fakultas peternakan IPB. Penanaman Indigofera zollingeriana dimulai dengan persemaian di tempat semai (seeding tray/baki) yang berisi tanah dan kompos dengan perbandingan $1: 1$, benih langsung ditabur secara merata ke permukaan media tanam pada baki. Penyiraman dilakukan hati-hati agar kecambah tidak rusak, tidak tergenang. Hari ke 7-10 dipindahkan ke polibag ukuran $0,5 \mathrm{~kg}$ masing diisi satu tanam Indigofera zollingeriana sampai umur 8 minggu. Tanaman kemudian dipindahkan kepetakan percobaan yang telah disiapkan sesuai dengan jarak tanam.

\section{Pemanenan}

Setelah 3 bulan ditanam kemudian tanaman dipotong pada ketinggian 1,25 m dari atas permukaan tanah. Pemanenan dilakukan pada interval 30 hari, 40 hari, 50 hari, dan 60 hari. Pemangkasan Indigofera dilakukan 1,25 $\mathrm{m}$ dari atas permukaan tanah. Panen dilakukan dengan memotong bagian tajuk tanaman, kemudian daun dan batang dipisahkan. Sampel Indigofera zollingeriana dikeringkan di bawah sinar matahari.

\section{HASIL DAN PEMBAHASAN}

Produktivitas indigofera dapat diekspresikan melalui produksi berat daun dan batang baik segar maupun kering, serta rasio daun batang. Pengaruh pemotongan interval Indigofera zollingeriana terhadap berat daun segar, berat batang segar, berat

Tabel 1. Berat Segar Daun dan Batang (g/tanaman)

\begin{tabular}{lcccc}
\hline \multirow{2}{*}{ Variabel } & \multicolumn{4}{c}{ Perlakuan } \\
\cline { 2 - 5 } & $\mathrm{I}_{1}$ & $\mathrm{I}_{2}$ & $\mathrm{I}_{3}$ & $\mathrm{I}_{4}$ \\
\hline Berat daun segar & $88,52^{\mathrm{c}}$ & $105,16^{\mathrm{bc}}$ & $122,32^{\mathrm{ab}}$ & $150,28^{\mathrm{a}}$ \\
Berat batang segar & $26,60^{\mathrm{c}}$ & $33,60^{\mathrm{bc}}$ & $40,22^{\mathrm{b}}$ & $63,60^{\mathrm{a}}$ \\
Berat daun kering & $16,23^{\mathrm{c}}$ & $23,08^{\mathrm{bc}}$ & $32,79^{\mathrm{ab}}$ & $38,22^{\mathrm{a}}$ \\
Berat batang kering & $9,92^{\mathrm{c}}$ & $11,50^{\mathrm{bc}}$ & $14,28^{\mathrm{b}}$ & $18,15^{\mathrm{a}}$ \\
Rasio daun/batang & $1,62^{\mathrm{b}}$ & $1,99^{\mathrm{b}}$ & $2,31^{\mathrm{a}}$ & $2,11^{\mathrm{a}}$ \\
\hline
\end{tabular}

Keterangan: Superskrip yang berbeda pada baris yang sama menunjukkan berbeda sangat nyata $(\mathrm{P}<0,01)$ 
daun kering, berat batang kering dan rasio daun batang dapat dilihat pada Tabel 1 .

\section{Pengaruh Perlakuan Terhadap Berat Segar dan Kering Daun}

Pengaruh interval pemotongan terhadap berat segar dan berat kering daun dapat dilihat pada Tabel 1. Berat segar daun pada interval pemotongan 30, 40, 50 dan 60 hari berturut-turut 88,52 gram, 105,16 gram, 122,32 gram dan 150,28 gram. Prayoga et al. (2018) melaporkan bahwa hasil produksi segar berdasarkan umur panen dalam perlakuan 40, 55, 70, dan 85 hari secara berturut-turut yaitu 1.614.788,83 g/ha 1.986.734,58 g/ha, 2.821.344,54 g/ha, dan 3.547.092,33 g/ha. Perbedaan umur panen akan mengakibatkan adanya perbedaan kuantitas penyerapan serta penerimaan cahaya matahari. Tinggi rendahnya kuantitas penyerapan serta penerimaan cahaya matahari berimbas pada intensitas metabolisme hijauan, semakin lama umur panen maka, intensitas metabolisme akan meningkat (Prayoga et al., 2018).

Hjauan pakan yang dipanen pada umur Berat kering daun pada interval pemotongan 30, 40, 50 dan 60 hari berturutturut 16,23 gram, 23,08 gram, 32,79 gram dan 38,22 gram. Hasil penelitian Setiyaningrum et al. (2017) menyatakan rata-rata produksi berat kering hijauan Indigofera zollingeriana dengan interval pemotongan 45, 60, 75, dan 90 hari yaitu, $150.300 \quad \mathrm{~g} /$ pohon/tahun, $\quad 326.900$ g/pohon/tahun, $533.410 \mathrm{~g} /$ pohon/tahun, dan $802.070 \mathrm{~g} /$ pohon/tahun.

$$
\text { Hasil analisis keragaman }
$$
menunjukkan bahwa interval pemotongan memberikan pengaruh yang berbeda sangat nyata $(\mathrm{P}<0,01)$ terhadap berat segar dan berat kering daun. Uji Beda Nyata Jujur menunjukkan bahwa interval pemotongan 60 hari menghasilkan berat segar dan berat kering daun yang sangat nyata lebih tinggi dari interval pemotongan 30 dan 40 hari tetapi, berbeda tidak nyata $(\mathrm{P}>0,05)$ dari interval pemotongan 50 hari. Hal ini disebabkan karena adanya kecenderungan perubahan produksi segar dan kering seiring dengan lama umur pemotongan dikarenakan proporsi bahan kering yang dikandung oleh suatu tanaman berubah seiring dengan umur tanaman (Mansyur $e t$ al., 2005). Menurut Aulia et al. (2005) Semakin tua umur tanaman maka kadar airnya akan semakin menurun dan kadar bahan keringnya meningkat. Adanya pengaruh umur pemotongan terhadap kadar air tanaman juga disebabkan tanaman yang masih muda mempunyai sel aktif untuk melakukan proses pembelahan sel maupun pembentukan jaringan.

\section{Pengaruh Perlakuan Terhadap Berat Segar dan Kering Batang}


Pengaruh interval pemotongan terhadap berat segar dan berat kering batang dapat dilihat pada Tabel 1. Berat segar batang pada interval pemotongan 30, 40, 50 dan 60 hari berturut-turut 26,60 gram, 33,60 gram, 40,22 gram dan 63,60 gram. Menurut Prayoga et al. (2018) hasil produksi batang segar berdasarkan umur panen dalam perlakuan 40, 55, 70, dan 85 hari secara berturut-turut yaitu, 18.890.000 $\mathrm{g} / \mathrm{ha}, 22.600 .000 \mathrm{~g} / \mathrm{ha}, 25.490 .000 \mathrm{~g} / \mathrm{ha}$, dan 27.510.000 g/ha. Berat kering batang pada interval pemotongan 30, 40, 50 dan 60 hari berturut-turut 9,92 gram, 11,50 gram, 14,28 gram dan 18,15 gram. Roni dan Lindawati (2019) melaporkan bahwa rata-rata berat kering Indigofera zollingeriana adalah 2,10 g/pohon, 5,33 g/pohon, 5,40 g/pohon, 5,40 g/pohon, 5,97 g/pohon, 6,13 g/pohon, dan $8,13 \mathrm{~g} /$ pohon.

Hasil analisis keragaman menunjukkan bahwa interval pemotongan memberikan pengaruh yang berbeda sangat nyata $(\mathrm{P}<0,01)$ terhadap berat segar dan berat kering daun. Uji Beda Nyata Jujur menunjukkan bahwa interval pemotongan 60 hari menghasilkan berat segar dan berat kering batang yang sangat nyata lebih tinggi dari interval pemotongan 30 dan 40 hari tetapi, berbeda tidak nyata $(\mathrm{P}>0,05)$ memberikan pengaruh yang berbeda sangat nyata $(\mathrm{P}<0,01)$ terhadap rasio daun/batang. Uji Beda Nyata Jujur menunjukkan bahwa interval pemotongan 50 hari menghasilkan dari interval pemotongan 50 hari. Hal ini disebabkan karena interval pemotongan yang lebih lama akan memberikan kesempatan yang lebih banyak terhadap hijauan Indigofera zollingeriana untuk melakukan proses metabolisme, aktivitas fotositesis, dan penyimpanan nutrisi. Rochiman et al. (2000) yang menyebutkan bahwa interval pemotongan yang panjang memberikan produksi kumulatif berat kering lebih tinggi dari pada interval pemotongan yang pendek.

\section{Pengaruh Perlakuan Terhadap Rasio Daun/Batang}

Pengaruh interval pemotongan terhadap rasio daun/batang dapat dilihat pada Tabel 1. Rasio daun/batang pada interval pemotongan 30, 40, 50 dan 60 hari berturut-turut 1,62, 1,99, 2,31 dan 2,11. Hasil ini mirip dengan penelitian Anis et al. (2019) menyatakan bahwa hijauan Indigofera zollingeriana yang ditanam selama 12 minggu di bawah naungan pohon kelapa memilki rasio daun/batang yaitu, 1,72, 1,78, dan 1,81. Menurut Ali et al, (2014) ratio daun/batang Indigofera yaitu, $0,8,1$, dan 1,4 .

Hasil analisis keragaman menunjukkan bahwa interval pemotongan daun/batang yang sangat nyata lebih tinggi dari interval pemotongan 30 hari dan 40 hari tetapi, berbeda tidak nyata $(\mathrm{P}>0,05)$ dari interval pemotongan 60 hari. Hal ini 
disebabkan karena faktor-faktor eksternal tanaman yang bervariasi seperti, pengairan, dan intensitas cahaya untuk fotosintesis. Menurut Tarigan et al. (2010), rasio daun/batang meningkat sejalan dengan semakin pendeknya interval pemotongan. Shehu et al. (2001) dan Herdiawan et al. (2014) menyatakan bahwa rasio daun/batang pada leguminosa pohon sangat penting, karena daun merupakan organ metabolisme dan kualitas leguminosa pohon dipengaruhi oleh rasio daun/batang jika semakin banyak jumlah daun, kualitas leguminosa tersebut semakin baik, karena daun merupakan bagian jaringan tanaman yang memiliki kandungan nutrisi paling tinggi dibandingkan dengan batang/ranting.

\section{KESIMPULAN}

Produktivitas Indigofera zollingeriana tertinggi yaitu pada umur pemotongan 50 hari dengan menghasilkan rasio daun/batang yang tertinggi.

\section{DAFTAR PUSTAKA}

Ali, A., L. Abdullah, P. D. M. H. Karti, M.A. Chozin, dan D.A. Astuti. 2014. Production and nutritive value of Leucaena leucocephala in peatland. Animal Production 16(3):156-164.

Anis, S D., Ch. L. Kaunang, M.M. Telleng, W.B. Kaunang, C.J. Sumolang, dan U. Paputungan. 2019. Preliminary evaluation on morphological response of Indigofera zollingeriana tree legume under different cropping patterns grown at 12 weeks after planting underneath mature coconuts. Livestock Research for Rural Development. Volume 31, Article \#132.

Aulia, F., Erwanto, dan Wijaya A.K. 2017. Pengaruh umur pemotongan terhadap kadar air, abu, dan lemak kasar Indigofera zollingeriana. Jurnal Riset dan Inovasi Peternakan. 1 (3):14.

Ering, V. J., M.M. Telleng, A. Rumambi, C.I.J. Sumolang. 2019. Pengaruh jarak tanam Indigofera zollingeriana terhadap kapasitas tampung potensial ternak sapi di areal pertanaman kelapa. Zootec 39(2): 380-386.

Herdiawan, I. 2013. Pertumbuhan tanaman pakan ternak leguminosa pohon Indigofera zollingeriana pada berbagai taraf perlakuan cekaman kekeringan. Jurnal Ilmu Ternak dan Veteriner. 18:258-264.

Herdiawan, I. dan R. Krisna. 2014. Produktivitas dan pemanfaatan tanaman leguminosa pohon Indigofera zollingeriana pada lahan kering. Jurnal Wartazoa 24(2): 75-82.

Mansyur, H. Djuned, T. Dhalika, S. Hardjosoewignyo, dan L. Abdullah. 2005. Pengaruh interval pemotongan dan inveksi gulma Chromolaena odorata terhadap produksi dan kualitas rumput Brachiaria humidicola. Media Peternakan 28(2): 77-86.

Prayoga, I. K., F. Fathul, dan Liman. 2018. Pengaruh perbedaan umur panen terhadap produktivitas (produksi segar, produksi bahan kering, serta proporsi daun dan batang) hijauan 
Indigofera zollingeriana. Jurnal Riset dan Inovasi Peternakan 2(1): 1-7.

Rochiman, K., S. Harjosoewignyo, dan A. Surkati. 2000. Pengaruh pupuk kandang, urea, dan interval pemotongan terhadap produksi serta ketahanan Stylosanthes guyanensis. Bul. Agr. 14(2): 15-22.

Roni, N. G. K. dan S. A. Lindawati. 2019. Produktivitas tanaman gamal (Gliricidia sepium) dan Indigofera (Indigofera zollingeriana) yang diberi berbagai dosis pupuk bioorganik. Jurnal Pastura 8(2): 105 109.

Setiyaningrum, E., I.N. Kaca, dan N.K.E. Suwitari. 2017. Pengaruh umur pemotongan terhadap produksi dan kualitas nutrisi tanaman Indigofera (Indigofera Sp). Jurnal Gema Argo. 23(1): 59-62.
Shehu, Y., W.S. Alhassan, U.R. Pal, C.J.C. Phillips. 2001. Yield and chemical composition response of Lablab purpureus to nitrogen, phosphorus and potassium fertilizers. Trop Grassl. 35:180-185.

Steel, R. C. dan Torrie J. H. 1995. Prinsip dan prosedur statistika. Gramedia Pustaka Utama. Jakarta.

Tarigan, A., L. Abdullah, S.P. Ginting, dan I.G. Permana. 2010. Produksi dan komposisi nutrisi serta kecernaan in vitro Indigofera sp. pada interval dan tinggi pemotongan berbeda. Jurnal Ilmu Ternak dan Veteriner 15:188195.

Telleng, M. M., K.G. Wiryawan, P. D. M. H. Karti, I.G. Permana, dan L. Abdullah. 2016. Forage production and nutrient composition of different Sorghum varieties cultivated with Indigofera in intercropping system. Media Peternakan 39 (3) : 203-209. 